\title{
IDENTITY AND TEMPORAL PERSPECTIVE OF ADOLESCENTS WITH HIGH ACHIEVEMENTS IN SCHOOL
}

\author{
Denitsa Alipieva \\ Faculty of Natural Sciences and Education, \\ University of Ruse "Angel Kunchev", \\ 8 Studentska str., Ruse, Bulgaria \\ E-mail address: dalipieva@uni-ruse.bg
}

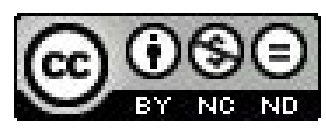

\begin{abstract}
The current article is an empirical approach reviewing the theories for the factors for formation of identity and self-conception in the adolescent. Under the theories for internal attribution and temporal perspective the study was conducted with teenagers between 11 and 18 years with different achievements. The aim is to show the relevance between the subjective affective involving and success in academic activity and realistic self-esteem that could enhance the abilities of students to create adequate plans and goals for future and mature self-conception.
\end{abstract}

Key words: identity, temporal perspective, achievement

\section{INTRODUCTION}

Competence and abilities are valued personal qualities in the contemporary globalized world. The place where they can be recognized and developed is the school. They have important roles not only to educational and professional success but also for process of self-assessment and planning of future goals that a subject will achieve in future. Recent Bulgarian researches on identity have studied an occurrence of statuses of psychosocial and national identity in examples of adolescents and adults (Baychinska, Bakracheva \&Savova, 2009; Baychinska \& Bakracheva, 2007; Baychinska \& Savova, 2008); styles and functions of identity (Bakracheva, 2011); relevant to identity constructs - hierarchy of values, personal crisis and subjective psychological wellbeing (Baychinska, 1994, 2000; Baychinska et al., 2009; Baychinska \& Garvanova, 2006).

The focus of current research on the achievements of adolescents is not fortuitous. This study aims not only to examine the impact of a sense of success on personal welfare but also it helps us to understand the role of achievements for formation of stable and adequate self-esteem and life planning. The last assumption is directly connected with the process of crystallization of identity. In this way, we investigate the significance of the achievements in the concrete academic or professional domain for formation of mature self-conception. 


\section{THE RELATION BETWEEN IDENTITY, ACHIEVEMENTS AND TEMPORAL PERSPECTIVE}

A productive body of research on adolescent identity development has presented numerous and multiple agents in formation of self-conception of teenagers and the overall process of maturing in this age period. The factors for emerging of academic achievements are multitudinous while those for identity formation countless. Different theories on identity in adolescence connect crystalized, mature self-conception to identifications with internalized models from family members (Erikson, 1956; Frank, Pirsch \& Wright,1990), family patterns of upbringing and socialization (Hamachek, 1978; McArdle \& Duda, 2004), specific manner of selfperception and self-monitoring (Berzonsky, 1989,1990; Miller \& Thayer, 1988; Snyder, 1987), internal locus of control (Schank \& Ableson, 1977), etc. It is an obvious fact that it is impossible to study and assess all these determinants of identity. We need to mark those ones that: first, have critical impact on the personal growth; and second, could be controlled and shaped by the adults with various psychological and pedagogical interventions.

The relationship between identity agency and academic achievements is one of most disputed themes in theory and practice. The identity achievement is accepted as a clear determinant of academic success (Berger, 1998; Berzonsky, 1989). For example, Lange and Byrd (2002) found that students in first course in university with status of achieved identity use more effective techniques for learning and are more accurate in self-monitoring activities and predicting of their success in concrete subjective ways than students with other identity statuses.

Seymour Epstein (1973) suggests that the identity structure is based on implicit "theory" of subject for own personality. In other words, the individual interpretations of information about himself/herself from inner and outer space (Erikson, 1956) are placed in field called self-schema (Shank \& Ableson, 1977). Michael D. Berzonsky (1990) claims that this "theory for self" is determined from the identity status, which in turn defines the process orientation of identity (Berzonsky, 1989a). Edward Sampson (1978) connects it with internal and external localization of identity showing how preferences toward sources of information of self (from social contacts or own mental work) and locus of control define the stability and type of identity.

In a large study in the Netherlands Harke Bosma (1992) defines the domains where adolescents invest time and efforts: education/profession, spare time, friendships, parents/home. These spheres could connect with different identity status. This idea is consistent with the theoretic perspective unifying self-monitoring in different academic and social contexts. Individuals with high self-monitoring have pragmatic self-conception that defines their mentality and behavior in specific social situations and the roles in them. They have "flexible self in current situation" (Snyder, 1987, p. 48). By contrast, people with low self-monitoring usually have principle based concept, that is based on a stable internal notion for self but they are less flexible in different social situations. Mark L. Miller and Julian F. Thayer (1988) show relation between high and low self-monitoring and the influence of internal and external sources in identity formation. Verta Taylor (1987) 
proves that low self-monitoring is associated with achieved identity, and high with moratorium and foreclosure. M. D. Berzonsky (1989) found that adolescents who have not mature self-conception are more likely to internalize the mentions of others for them and in this way became more role diffused than individuals from other statuses of identity (Marcia, 1980; Waterman, 1984).

The role of academic achievements for identity formation in the literature from both sides of Atlantic is viewed via performance in different school situations, academic involvement or delay that authors associate with different statuses of identity (Shahanan \& Pychyl, 2007; Schounberg, Lay, Pychyl \& Ferrari, 2004; Pychyl, Coplan, \& Reid, 2002; Lay, 2004; Cote \& Levine, 2002; Ferrari, Wolfe, Wesley, Scholl \& Beck, 1995). A refusal of school duties is object of analyses with identity long ago. For example, in the study of Henry C. Schouwenburg, Clarry H. Lay, Timothy A. Pychyl and Joseph R. Ferrari (2004) academic achievements are associated with personal traits as school delay is viewed as problem with self-regulation (Van Eerde, 2000), as self-mutilation (Ferrari \& Tice, 2000), inadequate self-esteem (Pychyl, Coplan \& Reid, 2002) and other aspects of self-image.

The correlation between identity statuses and school procrastination directly is studied from Joseph R. Ferrari, Raymond N. Wolfe, Joseph C. Wesley, Lisa A. Schoff and Brett L.Beck (1995), who examine relation between identity process and dropping out from school. The participants were divided into two groups: informative and diffused style of procession in the Michael Berzonsky's schema. In the end the authors found positive correlation between diffused style and early drop-out from school and negative - with informative style.

On the other hand Ego-identity correlates stability with forms of affiliation and cooperation in school work of adolescents (Swartz, Cote\&Arnett, 2005; Adams, 1998; Zhu, 2004; Beswick\&Mann, 1994; Blunt\&Pychyl, 2005; Shananan\&Pychyl, 2007). Academic involvement is "belief that a person may control his/her decisions and is responsible for results from them" (Swartz et al, 2005, p. 207). Seth Swartz, James Cote and Jeffrey Arnett (2005) define it as connected with selfexploration, flexible engagement, free choice, that are characteristics of mature identity. At the same time academic involvement is not connected with forms of weak goals and conformism that are specific for the status of foreclosed identity. Finally there is negative correlation between refusal and aimlessness that are attributes of status of diffused identity. In status of moratorium there is trend of keeping the school duties and continuous exploration of personal abilities (also school ones). At the same time the moratorium combines achievements with diffusion of roles (Adams, 1998).

The study on relation between achievements and identity of Gerald Adams (1998) with Extended Objective Measure of Ego Identity Status (EOM-EIS) shows that persons with achieved identity became more orientated toward achievements. It was found that teenagers with mature self-conception are more likely to search good performance and achievements in comparison to their peers with foreclosure or diffusion (Francis, 1981). However, some researches do not found relationship between achievements and mature identity (Rodman, 1983; Grotevant \& Adams, 1984). 
The current study aims to find the correlation between academic involvement and motivation for learning - high achievements - stable orientation to success - clear temporal perspective and life planning - mature identity. The idea that high achievements correlate to attributional style controlled under internal localization of control is not new. Since the 70's. a large number of empirical studies (Berzonsky, 1989, 1990; Epstein, 1973; Schank \& Ableson, 1977; Snyder, 1987) was conducted to show the relevance of the profound education and high remarks in school for better future and life-planning where individuals invest their efforts, aspirations, ambitions, etc. This scientific and empirical trend still finds place in contemporary literature for the issue of identity and adolescence (DomuschievaRogleva \& Yancheva 2011; Frank, Pirsch \& Wright,1990; Schounberg, Lay, Pychyl \& Ferrari, 2004; Shananan\& Pychyl, 2007; Simons, Vansteenkiste, Lens \& Lacante, 2004).

Several Bulgarian studies have presented that professional orientation, personal autonomy and social achievements have important roles for self-determination and adequate self-esteem of youth (Baychinska \& Savova, 2008; Silgidjian, $1987,1992,1998)$. These researches point to self-approval as the most considerable value .At the same time, the enhanced interest in individualism and achievement often does not connect to clear and adequate temporal perspective and behavioral model for realization of personal goals (Silgidjian, 1998). In other words, young people often know what they want but rarely how to achieve it.

\section{OBJECTIVES}

Our goal was to examine if the subjective sense of competence and success and achieved temporal perspective are the main factors for identity development. In realization of this goal the study was oriented towards two experimental tasks: a) to find positive correlation between achievements of adolescents and achieved status of identity; $b$ ) to check out if this identity will be stable over time with researching the temporal perspective of teenagers.

The main research hypothesis of the current study is the thesis that between internal attribution of the adolescents and achieved identity status there is a positive relation. Internal attribution of abilities and possibilities of the individual lies at the root of the success in valued spheres of the person over time. In this way internal attributive style appears as a factor for realistic self-esteem and reduces diffusion of the various professional and ideological roles (Rusinova, 2003; Silgidjian, 1987, 1992). We have studied also the influence of temporal perspective of adolescents as a facilitator of continuity of their identity over time.

Our main hypotheses were: a) how many successes and sense of involvement in concrete academic or professional activity has a student in adolescence so he or she will have optimum chances to achieve congruent and mature identity (Study $1)$; b) as achievements could be a base for "summing" of our own personal and professional career this will enhance the process of the goal - planning for future and temporal perspective of individual (Study 2). 


\section{METHOD}

\section{Participants}

The research was derived in two studies: 1) Study 1 - examination of the incidence of the achieved and diffused identity in a sample of adolescents with different level of achievement in school or other professional area; 2) Study 2 - measuring the life span plans of the same participants.

In Study 1369 teenagers - 209 girls and 160 boys - in the age between 11- and 18-years old participated. Students were recruited through classes in language and mathematical schools after interview with their teachers to examine their achievements.

After the interview with their teacher and work with the school documentation for obtaining information for their educational success at different subjects in school this example was derived in four groups:

Experimental group of students with high achievements ( $\mathrm{n}=75)$-students with high qualities for attaining and reproducing academic or technical information that is near to expert level. They have received a prize or good places in Olympiads, national challenges, or attend professional groups that is not typical for their age;

Experimental group of students with moderate achievements $(\mathrm{n}=98)$ - scholars with excellent or very good reports for all or most of disciplines at curriculum at school. The difference from first group is that they have never attended Olympiads or have not achieved good scores in them.

Experimental group of students with average achievements $(\mathrm{n}=99)$ - usually they have average scores on most of subjects at school but could have one or two disciplines that inspire them and this further them to have higher performance on the concrete subject, task or activity;

Experimental group of students with poor achievements $(\mathrm{n}=97)$ - they have fair or poor scores in the school subjects and do not feel academically involved in school activity.

The size of these experimental groups is not accidental. We searched statistical significance of the future results by controlling the sizes of groups of students with different achievements that are comparatively equal.

Study 2 involved 75 participants because the long diagnostic procedure of causometric interview of Evgeniy Golovaha and Alexander Kronik (1981). In time we understood that this interview could be applied only to participants who are in late adolescence (16-18 years old). The interview was unsuccessful with younger students. That is why we chose 75 students - representatives of the four groups from Study 1, who are in the age between 16- and 18 - years old.

\section{Measures}

Ego Identity Scale (EIS). Our choice for EIS was determined from the fact that Ego Identity Scale is short, easy designed and highly objective questionnaire of orthodox Ericson's Ego Identity. For the first time EIS was published in 1977 in study of identity statuses of 14-18-years old participants from Allen L. Tan, Randall Jay Kendis, Judith T. Fine from University of Pittsburg and Joseph Porac 
from Rocherster (Tan, Kendis, Fine \& Porac, 1977). The main aim of the authors was to design a questionnaire that is brief and provides at the same time high reliability. EIS contains 12 items arranged in polar principle of the two subscales Achieved Identity and Identity Diffusion. The participant chooses between two opposite statements that indicate both of statuses. The authors avoided the socially desirable answers with the polar administration of the scale. The validation of the questionnaire was derived with inclusions of the subscales of interpersonal trust (Rotter, 1967), locus of control (Rotter, 1966), intimacy vs social isolation, liberalism (Tomkins, 1966) vs. dogmatism (Schulze,1969) in ideology. The last two subscales help to clarify the issue with the foreclosure and moratorium in the model of James Marcia (1966). The subscale of achieved identity in EIS positively correlates to liberalism and negatively to dogmatism. All subscales are homogeneously combined in the overall scales of Achieved Identity and Identity Diffusion. EIS follows the following criteria: a. it is easily fillable, contains 12 items and yet it is with high validity and reliability; b. it is an objective measure of Ericson's identity statuses; c. empirically excludes various forms of dispersion and contamination of the results.

Causometry. The causometric method was created from the soviet psychologists E.I. Golovaha and A.A. Kronik in 1981 (Golovaha and Kronik, 1981) and includes empirical explorations of temporal perspective of Igor Cotel for the momentary and extended psychological and social time. This method is developed in the process of operationalization of the main sets in the causal conception for psychological time. Its denomination comes from the Latin words causa (cause) and metrum (measure) and shows its main task - to reveal the concepts of individual for causal and target links between the main events in his/her life. At the same time causometry differs from the typical biographical methods that are concerned only with past events and includes present and future, potential situations in life. The format of the causometry is individual interview with the participant and has four stages: preparation of the list with 15 events in the past, present and future of the individual; nomination of the dates (even for future events) of proposed events; causal analyses of the links between the situations in the life and their target analyses. The events are all big changes in the psychological time that could appear in the next domains: society, nature, values, health, family, education and career, communication and activities (Golovaha \& Kronik, 1981). In this way the adequacy of the formatting of adolescence temporal perspective can be checked by assessment of: a. the location of events in the sets of time, showing up the role of internal attribution for life planning and identity, and $b$. the main spheres that students involve their fetch and ambitions.

\section{Procedure}

The study was conducted in four stages: a. preoperational - the experimental groups with different achievements were defined by preparation work with school documentation and interview with teachers of the students who participated in the study; b. Study 1 - conducting of the testing with EIS with 369 students between age 11-18 years old. The questionnaire was presented by one researcher 
in different grades in schools in Ruse, Bulgaria, and administration lasted 25 minutes; c. Study 2 - 75 participants from the samples from Study 1 in late adolescence - 16-18 years old, were interviewed with method of causometry. The interview lasted between 40 and 60 minutes and was conducted in individual format.

\section{RESULTS AND DISCUSSION}

Study 1.The data gathered with the questionnaire and interview was analyzed with the program STATGRAPHICS (ST). Preliminary analyses categorized raw scores of the adolescents from EIS into two scales Achieved and Diffused Identity with normative means $M>6.000, S D<1.000$. Group means, standard deviations, quotient of variety and standard error were calculated for the both identity statuses and then the mean and standard deviation were summed to define the normative mean for each status. Finally, every scale was tested with coefficient of correlation of Pierson. Current study with EIS in Bulgarian sample, irrespective of the four experimental groups of achievements in Study 1, showed for Achieved Identity scale results with means of $7.360(\mathrm{SD}=1.912, \mathrm{~V}=25.974 \%)$ and for Diffused Identity scale means of $4,607(\mathrm{SD}=1.888, \mathrm{~V}=40.985 \%)$. These indexes have only informative value as the samples in the study was formed to the level of achievement and are not casual and representative for the overall population of peers in Bulgarian schools.

The statistic data of identity statuses in four samples, formed via level of academic achievements (Table 1) shows a tendency to statistically highest results for Achieved identity in the first sample with eminent achievements $(M=8.11184$, $\mathrm{SD}=1.53808)$ and lowest in the fourth sample with poor achievements $(M=6.86697$, $\mathrm{SD}=1.53808$ ). Participants with average achievements have small benefits in forming in identity ( $M=7.408163)$ compared to the third group with moderate achievements ( $M=7.288866)$. The correlation coefficient of Pierson showed significant relationship between achieved identity status and level of achievement $(0.2012$ and 0.0001). Consequently the experimental hypothesis for significant relation between achievements and identity could be partially accepted.

Tab.1. Descriptive data for identity statuses in samples formed by achievements (369).

\begin{tabular}{|l|c|c|}
\hline & Achieved Identity & Diffused Identity \\
\hline \multirow{2}{*}{ Sample 4. Poor achievements } & 6.865979 & 5.134021 \\
& $(1.53808)$ & $(1.53808)$ \\
\hline \multirow{2}{*}{ Sample 3. Average achievements } & 7.408163 & 4.591837 \\
& $(1.43940)$ & $(1.43940)$ \\
\hline \multirow{2}{*}{ Sample 2. Moderate achievements } & 7.288667 & 4.71134 \\
& $(1.42347)$ & $(1.42347)$ \\
\hline \multirow{2}{*}{ Sample 4. High achievements } & 8.1118421 & 3.881579 \\
& $(1.53808)$ & $(1.53808)$ \\
\hline
\end{tabular}


Study 2.The causometric interview was conducted with 75 participants of age between 16-18 years old because this method was not applicable for younger adolescents. This led to the differences in descriptive data in identity statuses in Study 1 . Normative means and standard deviations were calculated for the overall number of proposed of participants events, their spread in the time sets - past, present and future and different domains - society, nature, , values, health, family, education and career, communication and activities.

Table 2 represents indexes of identity statuses and psychological time sets in four samples from Study 1:

Sample with poor achievements $(n=3$, middle age -16.2714$)$ - participants in this group have lowest result for achieved identity $(\mathrm{M}=6.00000, \mathrm{SD}=0.50000)$ and highest for identity diffusion $(M=6.00000, S D=0.50000)$. At the average rates they indicate only two events that spread in past and future. Psychological set of present does not exist in their rates at all;

Sample with average achievements $(n=18$, middle age -16.8889$)$ - with rates of $8.22222(\mathrm{SD}=1.8395)$ for achieved and 3.88888 (1.8395) for diffused identity, participants with average achievements are with sensitively higher results than previous sample: number of events - $\mathrm{M}=5.05556(\mathrm{SD}=2.82716)$. Distribution of events in time is also more synchronic. They have the highest number of events in future that means that they are searching more sets of potentialcontribution of their personalities in different sets than other groups;

Sample with moderate achievements ( $n=22$, middle age - 16.95238) - here rates of achieved identity is $7.95238(\mathrm{SD}=1.510823)$ and those of diffusion 4.04761 (1.510823). The tendency of enhancing of overall number of events is kept $(\mathrm{M}=6.57142, \mathrm{SD}=2.62857)$. All rates in temporal perspective raise except this of future;

Sample with high achievements ( $n=29$, middle age -16.86207$)$ - this group has highest results in almost all spheres except identity diffusion and the set of the future, that is lower even from previous group (see Table 2). This means that no matter that the students with high achievements point more events from other samples, they choose concrete potential events that are connected with their ideological, moral and professional development in future.

Tab.2. Descriptive rates of samples of achievements from causometric parameters of psychological time (75)

\begin{tabular}{|c|c|c|c|c|c|c|}
\hline & $\begin{array}{l}\text { Achieved } \\
\text { identity }\end{array}$ & $\begin{array}{l}\text { Identity } \\
\text { diffusion }\end{array}$ & $\begin{array}{l}\text { Number of } \\
\text { events }\end{array}$ & $\begin{array}{l}\text { Events in } \\
\text { past }\end{array}$ & $\begin{array}{l}\text { Events in } \\
\text { present }\end{array}$ & $\begin{array}{l}\text { Events in } \\
\text { future }\end{array}$ \\
\hline $\begin{array}{l}\text { Poor } \\
\text { achievements }\end{array}$ & $\begin{array}{l}6.0000 \\
(0.500)\end{array}$ & $\begin{array}{l}6.0000 \\
(0.500)\end{array}$ & $\begin{array}{l}2.0000 \\
(1.000)\end{array}$ & $\begin{array}{l}1.32907 \\
(0.67093)\end{array}$ & $\begin{array}{l}0 \\
(0)\end{array}$ & $\begin{array}{l}0.816665 \\
(0.500)\end{array}$ \\
\hline $\begin{array}{l}\text { Average } \\
\text { achievements }\end{array}$ & $\begin{array}{l}8.22222 \\
(1.8395) \\
\end{array}$ & $\begin{array}{l}3.88888 \\
(1.8395) \\
\end{array}$ & $\begin{array}{l}5.05556 \\
(2.82716) \\
\end{array}$ & $\begin{array}{l}2.4444 \\
(1.56724) \\
\end{array}$ & $\begin{array}{l}0.72222 \\
(0.76266)\end{array}$ & $\begin{array}{l}3.1111 \\
(1.44444)\end{array}$ \\
\hline $\begin{array}{l}\text { Moderate } \\
\text { achievements }\end{array}$ & $\begin{array}{l}7.952381 \\
(1.510823) \\
\end{array}$ & $\begin{array}{l}4.047619 \\
(1.510823) \\
\end{array}$ & $\begin{array}{l}6.571429 \\
(2.628571) \\
\end{array}$ & $\begin{array}{l}3.33333 \\
(1.909091) \\
\end{array}$ & $\begin{array}{l}0.809521 \\
(0.662388) \\
\end{array}$ & $\begin{array}{l}2.75000 \\
(1.87500) \\
\end{array}$ \\
\hline $\begin{array}{l}\text { High } \\
\text { achievements }\end{array}$ & $\begin{array}{l}8.724138 \\
(1,227586)\end{array}$ & $\begin{array}{l}3.275862 \\
(1.227586)\end{array}$ & $\begin{array}{l}7.586207 \\
(2.632184)\end{array}$ & $\begin{array}{l}3.793103 \\
(1.526437)\end{array}$ & $\begin{array}{l}1.862069 \\
(1.31954)\end{array}$ & $\begin{array}{l}1.931034 \\
(1.344828)\end{array}$ \\
\hline
\end{tabular}

Source: own research 
The next step in statistical analysis of the data from causometry was to define the occurrence of the rates in the domains society, nature, values and ideology, health, family, education and profession, activities and communication (Table 3, Figure 1). In this way we can see the main parameters of life planning and development of ideological, moral and professional engagements of forming personality in adolescence.

Tab.3. Diffusion of events in life domains from causometric interview (75)

\begin{tabular}{|c|c|c|c|c|c|c|c|}
\hline & Society & Nature & $\begin{array}{l}\text { Values, } \\
\text { ideology }\end{array}$ & Health & Family & $\begin{array}{l}\text { Education, } \\
\text { profession }\end{array}$ & $\begin{array}{l}\text { Activities, } \\
\text { communication }\end{array}$ \\
\hline $\begin{array}{l}\text { Poor } \\
\text { ach. }\end{array}$ & $\begin{array}{l}1.5000 \\
(1.5000)\end{array}$ & $\begin{array}{l}0 \\
(0)\end{array}$ & $\begin{array}{l}0 \\
(0)\end{array}$ & $\begin{array}{l}0 \\
(0)\end{array}$ & $\begin{array}{l}0 \\
(0)\end{array}$ & $\begin{array}{l}0.355905 \\
(0.711806)\end{array}$ & \begin{tabular}{|l|}
0 \\
$(0)$ \\
\end{tabular} \\
\hline $\begin{array}{l}\text { Average } \\
\text { ach. }\end{array}$ & $\begin{array}{l}0.22278 \\
(0.493827)\end{array}$ & \begin{tabular}{|l|}
0.1111 \\
$(0.197571)$
\end{tabular} & $\begin{array}{l}1.944444 \\
(1,15432)\end{array}$ & $\begin{array}{l}0.11111 \\
(0.209877)\end{array}$ & $\begin{array}{l}1.166667 \\
(0.796206)\end{array}$ & $\begin{array}{l}2.33333 \\
(1.473684)\end{array}$ & $\begin{array}{l}1.888889 \\
(1.590643)\end{array}$ \\
\hline $\begin{array}{l}\text { Moderate } \\
\text { ach. }\end{array}$ & \begin{tabular}{|l}
1.428571 \\
$(1.662358)$ \\
\end{tabular} & $\begin{array}{l}0.142857 \\
(0.233766)\end{array}$ & $\begin{array}{l}2.000000 \\
(1.72727) \\
\end{array}$ & $\begin{array}{l}0.095238 \\
(0.164502) \\
\end{array}$ & \begin{tabular}{|l|}
1.571429 \\
$(0.896104)$ \\
\end{tabular} & $\begin{array}{l}3.333333 \\
(1.424242) \\
\end{array}$ & \begin{tabular}{|l|}
1.476190 \\
$(1.606061)$ \\
\end{tabular} \\
\hline $\begin{array}{l}\text { High } \\
\text { ach. }\end{array}$ & $\begin{array}{l}0.62069 \\
(0.868966)\end{array}$ & $\begin{array}{l}0.068966 \\
(0.124138)\end{array}$ & $\begin{array}{l}1.37931 \\
(1.08046)\end{array}$ & \begin{tabular}{|l|}
0.310345 \\
$(0.434483)$
\end{tabular} & $\begin{array}{l}1.103448 \\
(0.724138)\end{array}$ & $\begin{array}{l}4.034483 \\
(2.03908)\end{array}$ & $\begin{array}{l}1.482759 \\
(1.17701)\end{array}$ \\
\hline
\end{tabular}

Source own research

Fig.1. Life planning in the domains from causometric interview in the four samples (75)

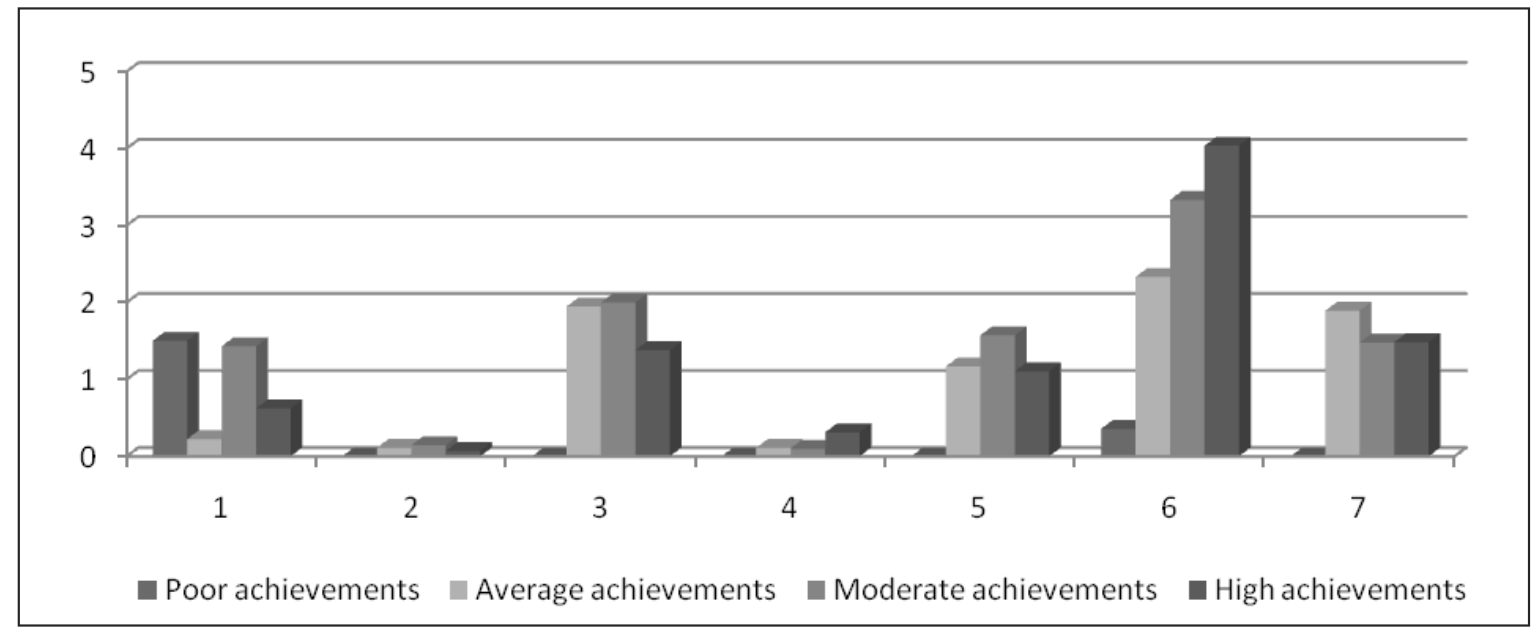

Legend: 1-society, 2 - nature, 3- values and ideology, 4- health status, 5- family and household, 6 - education and career,7 - communication, hobby and activities

Source: own research

The correlation analysis showed that only in the domain of education and career can be seen a small increase with the level of achievements in the samples $(p=0.0021)$. This escalation was expected because the experience of participants with higher achievements in different academic activities, their success in them and higher motivation for achievements in school. In this way the experienced success and sense of academic involvement have effect on the choices that adolescents make in their future educational and professional development. Students from last sample with high achievement often participate in Olympiads, acade- 
mic competitions and festivals and in this way they could "try" and raise their competence. This fact leads them to see their past and present full with academic successes and to plan their career in this area in future.

Level of achievements does not influence on other domains in causometry. Usually all participants in the study mark more events in the professional, ideological, family and activity fields. It is interesting that next to professional domain is ideological one that means that adolescents search personality growth, independency and stability. Clearly the third domain is family and household as expected, normative change in life. Their choices depend on many extrapersonal and intrapersonal factors - personal traits, activity of will, consciousness/ unconsciousness and locus of control, family patterns, reference groups, society values, etc.

Research works on temporal perspective, internal attribution and identity of individuals in adolescence always are problematic and strenuous, because they include concepts, which are cross-modal, with low categorical purity. This fact leads to theoretical and empirical discussions in scientific literature. Current study attempts to clear the categorical coverage of the phenomena of identity processes by their differentiation and integration in holistic schema that is near to the self-conception of self-identifying teenager.

The scope on the early adolescence (11-15-years old) is applied by reason of sensitivity and criticality in this period for the further development of congruent identity by overcome of the sense of personal crisis. This crisis includes dissociation of temporal, individual emotional, mental and social level of self and sense of lack of congruity and personal significance.

The results from statistical analysis proved partial influence of achievements to identity. It is partially because this relation was detected only in the sample of participants who show clear orientation to competence and motivation for education as immanent personal traits. Except internal attribution other factors have also important roles in identity agency and also must be researched - parents and peers aspirations and influence, values and social categorizations in reference groups, social facilitation and affiance, etc.

The narrow correlation between achievement/academic involvement and developed and synchronic temporal perspective demonstrated the sense of attributional style and adequacy of self-esteem for further potential choices and invests of individual.

We can draw the following conclusions:

Temporal perspective is developing from end of early and beginning of late adolescence. It is expressed in enrichment and detailing of the past, present and future personality projections at the time. The number of actual events increases, showing the willingness for realization and start of the future plans and successes in future;

In late adolescence life plans include development that is oriented toward self-realization, autonomy, professional growth, ideological power of personality and creation of household;

There was not found clear relation between level of achievement and identity statuses and the results showed only indirect influence. This means that future 
researches of identity process need to focus on the intrapersonal factors and influence of social surroundings for identity achievements;

Clearest is the relationship between achievements and temporal projection that has specific characteristics: decrease of emotional involvement in the past, presence of more present events that grow later in future personal aims and ambitions in the future. In this way, how much more success has an individual in the concreate scientific or professional sphere, feels pleasure and is satisfied with activity, so much higher is the possibility this activity is to be involved as a personal aim in future life planning.

\section{CONCLUSION}

It could be concluded that different activities in school or other educational services have impact not only on the achievements, attributional style and motivation, but also on the self-esteem and life planning of adolescents. The developing role of activities is forced not only from sense of success, but also from the satisfaction and emotional involvement in the tasks. These are the main factors of engagement of adolescents with the educational and professional roles, highly valued by society. With forcing of self-esteem, internal attribution and temporal perspective by achievements we partially influence forming of identity. Still we need to examine the influence of family and peers surrounding and personal choice in process of crystallization of self-conception of adolescents. These conclusions submit some practical issues, concerning the quality of the examination of skills and abilities in schools. Their early and adequate diagnostics facilitates the efficient educational and professional orientation in the last grades. This service must not be realized in late adolescence when individual is on the verge of starting work or university. It must start earlier with assessment of potentials of individual and professional pedagogical and psychological diagnostics of abilities that could be developed over time. It is necessary to build an efficient aggregate of different educational services (circles, workshops, interactive and constructive learning, etc.) for the students with different potentials where they could train and interact. They can be a good basis for formation of realistic level of self-esteem by social comparison in one concurrent and in same time identical group of peers with same interests. This could lead to creation not only of good experts in future but also of humans with high aims and plans in future that respect knowledge, personal growth and autonomy.

\section{REFERENCES}

Adams, G.R. (1998). Objective measure of ego identity status: A reference manual. Retrieved from http:// www.uoguelph.ca/ gadams/OMEIS_manual.pdf

Adams, G. R., Abraham, K. G., \& Markstrom, C. A. (1987). The relationships between identity development and self-consciousness during middle and late adolescence. Developmental Psychology, 19. 292-297.

Bakracheva, М. (2011). Стилове и функции на идентичността [Styles and functions of identity]. Bulgarian Journal of Psychology, Journal of VI National Congress of Psychology.77-84. 
Baychinska, K. \& Savova, S. (2008). Статуси на национална идентичност, мотивация заемиграция и ценности юношеска възраст[Statuses of national identity, motivation for emigration and values in adolescence]. Retrieved from https://bjop.files.wordpress.com/2008/10/krasimira-baichinskasavka-savova-doklad1.pdf Baychinska, K. \& Bakracheva, M. (2007). Субективно психично благополучие на българите в кроскултурна перспектива [Subjective psychic wellbeing of Bulgarians in cross-cultural perspective]. Philosophical alternatives, 2-3. 32-46.

Baychinska, K. \& Garvanova, M. (2006). Ценности и ијенностна криза в прехода към демократично общество в България [Values and crisis of values in transition toward democratic society in Bulgaria], Bulgarian Journal of Psychology, 2. 54-69.

Baychinska, K. (1994). Ценности, иенностен стрес..Ценностна криза![Values, stress of values... Crisis!], Sofia: AI „Marin Drinov“.

Baychinska, K. (2000). Динамика в ценностната система на българина в прехода към демократично общество [Dynamics in Values of Bulgarian in transition toward democratic society], Sofia: Bulgarian Academy of Science, 5. 26-30.

Baychinska, K., Bakracheva, M. \& Savova, C. (2009). Сmamyси на психосоицална и национална идентичност, иенности и психично благополучие в юношеска възраст [Statuses of psychosocial and national identity, values and psychic wellbeing in adolescence], Sofia: AI "Marin Drinov“.

Berger, K. S.(1998). The Developing Person through the Life Span (4th ed.), New York: Worth.

Lange, C., \& Byrd, M. (2005). Differences between student's estimated and attained grades in a firstyear introductory psychology course as a function of identity development. Adolescence, 37 (145). $93-107$.

Berzonsky, M. D. (1989). Identity style: conceptualization and measurement. Journal of Adolescent Research, 4. 267 - 281.

Berzonsky, M. D. (1990). Self-construction over the life-span: A process perspective on identity formation. Advances in Personal Construct Psychology, 1. 155 - 186.

Berzonsky, M. D. (1995).The self as a theorist: Individual differences in identity formation. International Journal of Personal Construct Psychology, 2. 363 - 376.

Beswick, J. \& Mann, L. (1994). State orientation and procrastination.Toronto: Hogrefe \& Huber.

Blunt, A. \&Pychyl, T.A. (2005). Project systems of procrastinators:a personal project-analytic and action control perspective. Personality and Individual Differences, 38,1771 - 1780.

Bosma, H. A. (1992). Identity in adolescence: Managing commitments. In: G. R. Adams, T. P.Gullotta, \& R. Montemayor (Eds.), Adolescent identity formation: Advances in adolescent development: Vol. 4 . 91-121.

Cote, J. E. \& Levine, G. G. (2002). Identity formation, agency, and culture: a social psychological synthesis. Mahwah NJ: Lawrence Erlbaum.

Dilova, M., Lafchiyska, E, \& Georgieva, Y, (2011) Влияние на страха от успеха върху мотивацията за придобиване на образование и атрибутивния стил [The role of fear from success to motivation for education and attributional style], Bulgarian Journal of Psychology, Journal of VI National Congress of Psychology. 92-100.

Domuschieva-Rogleva, G. \& Yancheva, T. (2011).. Целевата ориентация към постижения и Аз-ерективност при състезатели от различни видове спорт [Goal orientation of achievements and self-effectiveness in athletes in different sports], Bulgarian Journal of Psychology, Journal of VI National Congress of Psychology, 100 - 105.

Epstein, S. (1977). The self-concept revisited: Or a theory of a theory. American Psychologist, 28. 404 $-416$.

Erikson, E. H. (1956). The program of ego identity. Journal of the American Psychoanalytic Association, 4. 56-121.

Ferrari, J. R. \& Tice, D.M. (2000). Procrastination as self-handicap for men and women: a task-avoidance strategy in a laboratory settings. Journal of Research of Personality, 34.73 - 83.

Ferrari, J. R., Wolfe, R. N., Wesley, J. C., Schoff, L. .A., \& Beck, B. L.(1995). Ego identity and academic procrastination among university students. Journal of College StudentDevelopment, 36. 361 - 367.

Francis, S. J. (1981). Dropout decisions perceived as a function of the relationship between identity status, locus of control and ego development: A developmental approach to retention and attrition. (Dissertation Abstracts International, 42, 4319A.

Frank, S. J., Pirsch, L.A., and Wright, V.C. (1990). Late adolescents' perceptions of their relationships with their parents: Relationships among deidealization, autonomy, relatedness and insecurity and 
implications for adolescent adjustment and ego identity status. Journal of Youth and Adolescence, 19. 571-588.

Ganeva, Z. (2010). Социални идентичности и субективно благополучие [Social identity and subjective wellbeing], Sofia: Valdeks.

Golovaha, A. \& Kronik, Е. (1981). Психологическое время личности [Psychological time of personality], Moscow: Naukova dumka.

Grotevant, H. D. \& Adams, G. R. (1984). Development of an objectivemeasure to assess ego identity in adolesce: validation and replication. Journal of Youth and Adolescence,13. 419 - 438.

Hamachek, D. E. (1978). Psychodynamics of normal and neurotic perfectionism. Psychology, 15. 27-33.

Lay, C. H. (2004). Some basic elements in counseling procrastination.In: Schounberg, H.C., Lay, C.H., Pychyl, T.A. \& Ferrari, J. R., Counseling of procrastination in academic settings(pp. 214-256).Washington DC: American Psychological Association.

Levterova, D. (2011). Идентичност и социална среда [Identity and social surroundings]. Personal and national identity, 1. Plovdiv, 5 - 28.

Marcia, J. E. (1980). Identity in adolescence. In: J. Adelson (Ed.): Handbook of adolescent psychology, New York: Wiley.

McArdle S. \& Duda J. (2004). Exploring Social-Contextual Correlates of Perfectionism in Adolescents: A Multivariative Perspective. CognitiveTherapyandResearch, 28. 765-788.

Miller, L. M. \& Thayer, F. J. (1988). On the nature of self-monitoring: Relationships with adjustment and identity. Personality and Social Psychology Bulletin, 29. 544-553.

Pychyl, T.A., Coplan, R.J. \& Reid, P.A. (2002). Parenting and procrastination: gender differences in the relations between procrastination, parenting style and self-worth in early adolescence. Personality and Individual Differences, 33. 271 - 285.

Sampson, E. (1978). Personality and the location of identity.Journal of Personality, 46. 552-568.

Schank, R. C. \&Ableson, R.P. (1977). Scripts, Plans, Goals, and Understanding: An Inquiry Into Human Knowledge Structures. Hillsdale, NJ: Lawrence Earlbaum.

Schounberg, H. C., Lay, C. H., Pychyl, T. A. \& Ferrari, J. R. (2004). Counseling of procrastination in academic settings. Washington DC: American Psychological Association. Shananan, M. J. \& Pychyl, T. A. (2007). An ego identity perspective in volitional action: Identity status, agency, and procrastination. Personality and Individual Differences, 43.901 - 911.

Silgidjian - Georgieva, H. (1998). Аз-концепция и психосоииална идентичност [Self-conception and psychosocial identity], Sofia: UI “Sv. KlimentOhridski."

Silgidjian, Н. (1985). Ценностни ориентации и времеви хоризонт на личността в юношеска възраст [Orientation of values and temporal horizon of personality in adolescence], Psychology,4. 17-32.

Silgidjian, Н. (1992). Времева перспектива и модели на личностна промяна в жизнения път на човека [Temporal perspective and models of personality change in life span of human]. Change of human and the person of the change, Sofia: Bulgarian Academy of Science.

Simons, J.,Vansteenkiste, M.,Lens,W., \& Lacante,M.(2004).. Placing motivation and future time perspective theory in a temporal perspective. Educational Psychology Review, 16. 121-139.

Snyder, M. (1987). Public appearances/private realities: The Psychology of Self-Monitoring, New York: Freeman.

Tan, A., Kendis, R. J., Fine, J. \& Porac, J. (1977). A Short measure of Eriksonian Ego Identity, Journal of Personality Assessment, 41(3). 279-284.

Todorova, Е. (2006.) Активност и адаптаиия на личността - социална мотивация за успех [Activity and adaptation of personality - social motivation for success], Activity and adaptation of personality in conditions of changes, 1, Blagoevgrad, 17-26.

Van Eerde, W. (2000). Procrastination: self-regulation in initiating aversive goals. Applied Psychology: An International Review, 49.372 - 389.

Waterman, A. S.(1984). The psychology of individualism. New York: Praeger.

Zhu, J. (2004). The conative mind: Volition and action. Dissertation Abstract International 64 (10-A). 